\title{
Introduction: Evolving Perspectives on Working-Class Literature
}

John Lennon \& Magnus Nilsson

The main impetus to publish the first volume of Working-Class Literature(s): Historical and International Perspectives was simple: we were unhappy with the scholarly framing surrounding working-class literature. Excellent work was, of course, available, but much scholarship in our field was - in our view - too strictly nationalistic in outlook, too focused on the distant past, and too often theoretically outdated. As we present this second volume, we see that the scholarly framework has continued to evolve in exciting new directions.

Today, there is no lack of cutting-edge research on working-class literature and we are proud to recruit to our two edited collections junior and senior scholars who are innovatively exploring this literature. Together they will push working-class literary studies in new directions, challenging previously held beliefs about what working-class literature is and about who is writing it. They are building upon previous work but are also aware of the need to introduce new perspectives and to revise established literary histories.

Most exciting to us is that there are clear tendencies within this contemporary research to establish international connections among scholars while making salient transnational comparisons between different traditions of working-class literature and research. This reminds us of a beautiful scene early in Maxim Gorky's I906 classic novel Mother [Мать] depicting Russian workers surprised to read literature about workers in other countries.

How to cite this book chapter:

Lennon, J. and Nilsson M. 2020. Introduction: Evolving Perspectives on Working-Class Literature. In: Lennon, J. and Nilsson, M. (eds.) Working-Class Literature(s): Historical and International Perspectives. Volume 2. Pp. I-I4. Stockholm: Stockholm University Press. DOI: https://doi.org/Io.ı6993/bbf.a. License: CC-BY 4.0. 
The workers gain perspective and inspiration from these stories, allowing them to reimagine their own socio-political positioning. Likewise, we are thrilled to see our colleagues in countries throughout the world reading through these wide-angle national histories and collaborating on new international projects. We have been able to see this phenomenon at several recent working-class literature conferences.

For example, at the American Comparative Literature Association's conference in Los Angeles in 2018, scholars compared proletarian literatures from the U.S., Germany, the U.K., the Soviet Union, Sweden, China and Korea. A few weeks later, scholars discussed working-class literatures from Korea, Sweden, Germany and the U.K. during the workshop, "The Proletarian Moment: Interdisciplinary Approaches, Comparative Perspectives" at the Center for Interdisciplinary Research at the University of Bielefeld in Germany. In the summer of 2019, members of the research project "Piston, Pen \& Press - Literary Cultures in the Industrial Workplace from the Factory Acts to the First World War," which studies English and Scottish working-class literatures, and thus in itself includes an international dynamic, collaborated during a conference in Tampere, Finland in cooperation with the Finnish Labor Museum. The aim of this conference - which attracted participants from the U.K., Finland, Sweden, Russia and the U.S. - was to initiate international discussions about working-class literature while building international scholarly networks. A few weeks later, The Association for Working-Class Studies - the most important academic organization for scholars of working-class literature in the U.S. - located their nineteenth annual conference to Cambridge, England, marking its first meeting outside of the U.S., with the expressed purpose, as stated on their website, to "consolidate work being carried out currently in the UK and Europe with the USA and elsewhere in the world."

In 2020, two more conferences were to be held at the Museum of Labour History in Copenhagen, Denmark. At the Nordic Labour History Conference "Labouring Lives and Political Protest Across and Beyond the Nordic Countries" - which has been postsponed due to the corona pandemic - sholars from Sweden, Finland, and Denmark should have engaged in comparative discussions, while 
the conference organized by The Nordic Network for the Study of Working-Class Literature, which will take place digitally, will explore the theme of "international perspectives and connections" in Nordic working-class literatures.

Thus, the national (or even nationalistic) framework that troubled us in much previous research about working-class literature seems to be under greater scholarly pressure in recent years. The same can be said about the incorrect view of working-class literature existing only as a historical phenomenon. Deindustrialization, the rise of neoliberalism and the subsequent attacks on unionism in many countries across the world have reshaped the working class. Working-class literature has, therefore, also changed; however, it has not disappeared. Scholars are contextualizing $2 \mathrm{I}^{\text {st }}$ century literature as a dialogue with the past by exploring our present literature within a historical tradition. For example, in recent years, Cambridge University Press has published three edited collections about the history of U.S., British, and Irish working-class literatures, all of which follow these literatures' development into our present age (Coles and Lauter, 20I7; Goodridge and Keegan, 2017; Pierse, 2018).

Thus, if we understood the first volume of Working-Class Literature(s): Historical and International Perspectives as an attempt to "disrupt narrow understandings" of the concept and phenomenon of working-class literature, we view this subsequent volume more as a contribution to a broad current of new scholarship about working-class literatures. We see much momentum among scholars to think about their national working-class literatures in context of a larger international and historical phenomenon, drawing comparisons that reexamine previously held beliefs. Because of this, working-class literary studies is in a great position to grow. This expansion is especially important in our contemporary moment when neo-liberal austerity governments, which do not look favorably upon our field, are increasingly slashing university budgets.

In the introduction to the previous volume, we stressed that we had no ambition to comprehensively overview all existing workingclass literature traditions. Even if the present book's publication means we have now gathered essays from more than a dozen 
countries, we repeat this disclaimer. Working-class literatures exist in many parts of the world, and to produce a comprehensive account of these literatures is well beyond our ambitions. We hope, though, the work begun in these two volumes continue and that editors and publishers look to boost the voices of scholars working on working-class literatures from all over the worldespecially from unrepresented nations. By spotlighting these literatures, we can have a more comprehensive understanding of bodies of previously overlooked literature.

Our goal for this collection is still a rather modest one: to give examples of different working-class literature traditions that contribute toward a more complex understanding of the global phenomenon of working-class literature(s). Taken separately, each chapter introduces a national tradition of working-class literature. Taken together, a larger more complex view of working-class literatures forms. Below, we will outline some of the important aspects of this view and the essays discussed in this collection. Our hope, though, is readers will identify other similarities and differences between these working-class literatures, adding to the ongoing scholarly debates about this phenomenon.

In her essay "Tales of Social Terror: Notes on Argentine WorkingClass Literature,” Anna Björk Einarsdóttir argues, in Argentina, the concept of working-class literature has not been widely used, and accounts of this literature have often been misconstrued. Because discussions of proletarian literature and committed aesthetics in Argentina have focused mainly on one writer - Elías Castelnuovo - the breadth of proletarian literature in Argentina has been obscured, and working-class literature has been reduced to a literature almost pathological in its naturalist and grotesque account of proletarian misery. By (re-) introducing and expanding the concept of working-class literature, Einarsdóttir moves beyond local terminology and critical accounts and seeks to open up a new space to examine what might count as Argentine working-class literature. This space is, in part, international, since the essay stresses the importance of seeing the local development of proletarian literature and politics in Argentina in the context of transnational developments. 
In the essay "Danish Working-Class Literature Past and, Perhaps, Present," Nicklas Freisleben Lund outlines the history of Danish working-class literature from the late nineteenth century to, perhaps, the present. The word "perhaps" is a nod to the many critics who, pointing to a drastic decline in scholarly interest in working-class literature since the I970s, have argued that this tradition has either ended or been actively silenced; however, according to Lund, it is mainly the concept of working-class literature that has disappeared from critical discourses. In his essay, Lund uncovers potential candidates for $2 \mathrm{I}^{\text {st }}$ century Danish workingclass literature that scholars have heretofore not described as such. By doing so, Lund argues a significant point that all contemporary scholars of working-class literature should heed: the working class in the $2 \mathrm{I}^{\text {st }}$ century has changed; so, too, have representations of this class. As we conceptualize working-class literature from an international perspective, Lund illustrates we must also be willing to expand our conceptions of it.

Hunter Biven's essay “Revisiting German ProletarianRevolutionary Literature" focuses primarily on one strand within the history of German working-class literature: the proletarianrevolutionary novel genre of the Weimar Republic. He offers a "revisionist" reading of this literature, focusing on the tensions between its status as a counter-or subcultural working-class practice on the one hand and, on the other hand, its ambitions to contribute to proletarian cultural hegemony in society at large. This relatively narrow focus might seem to contradict a goal in this volume to give overviews of national traditions. However, the history of German working-class literature is highly heterogenous and fragmented, which means it has been hard to view it as one unified tradition (Nilsson 20I4, 64-70). By exploring the proletarian-revolutionary novel genre, Bivens creates a comparison point with other strands in German literature as well as other national literatures.

In his essay, “The Proletarian Literature Movement: Japan's First Encounter with Working-Class Literature," Mats Karlsson also focuses on proletarian literature from the interwar period. In Japan, however, this literature constitutes the core of the tradition of working-class literature, since, as Karlsson points out, the 
vibrant Proletarian Cultural Movement initiative, which constituted its infrastructure, was virtually "shut down" by the authorities in the mid I930s. Nevertheless, Karlsson demonstrates how the literature of this proletarian moment, at least in some cases, has "aged well," and has relevance in today's political, economic, and cultural situation.

In "From Red Scare to Capitalist Showcase: Working-Class Literature from Singapore," Luka Zhang Lei delineates a historical overview of working-class literature in Singapore. She does so by focusing on three writers, Chong Han (I945-), Tan Kok Seng (1939-), and MD Sharif Uddin (I978-), who represent different "production modes" within this history and engages in critical dialogues with their receptions. Zhang begins by noting there is no recognized tradition of working-class literature in Singapore, and her aim is to contribute to the construction of such a discourse. In part, this means she re-reads literature that has previously not been understood as working-class literature. For example, in her reading of Chong Han, she proposes the concept of working-class literature as an alternative to that of communist propaganda, thereby making visible new aspects of his works. Zhang also uses the concept of working-class literature to challenge hegemonic discourses about literature in Singapore founded in racial, ethnic, and linguistic diversity, as well as to argue against the dominant idea that workers' literature is not "real" literature. Importantly, Zang introduces - and critiques the massive attention given to literary competitions for migrant workers in Singapore (and beyond) in recent years that she feels is part of capitalistic exploitation.

In the essay "The Hybridity of South African Working-Class Literature," Małgorzata Drwal offers an overview of this literature, focusing on its diversity in terms of, among other things, genres, forms, languages, audiences, and traditions. With the point of departure in the theoretical concept of "histoire croisée," Drwal also maps its relationships to both international and national processes, discourses, and conditions. The author also focuses on the similarities - for example expressions of pastoral nostalgia between different kinds of working-class literature. Like all of the essays in this collection, Drwal pushes against previous 
notions of what has previously been left out of South African working-class literature, expanding the frame and, thus, reimagining its tradition.

In "'A Pole of Differentiation': Pasts and Futures in Irish Working-Class Writing,” Michael Pierse continues his work found in his own edited collection The History of Irish Working-Class Writing (20I7): to explore Irish working-class literature in light of the recent reconceptualizations of Irish history that have stressed the nation's key role in the development in British imperialist capitalism, and the subsequent rediscovery of the Irish working class. His main claim is the writing that has emerged from, or represents, the Irish working class has been far more extensive and diverse than previously acknowledged in scholarship. His essay constitutes an attempt to open up and promote Irish workingclass literature as an area of academic inquiry that, because of its diasporic nature, demands both national and international framing.

To a large extent, the essays in this volume confirm many of our first volume's arguments:

a) National histories are important to understand. These understandings, though, are enriched and complicated when dialogued with other national working-class literatures.

b) These dialogues between national working-class literatures must consider local conditions and specificities. Generic working-class literature definitions that attempt to narrowly fit working-class literatures from all nations together are unproductive.

c) Histories of working-class literature must do more than identify writers from the working class or literary works depicting workers and detail the construction of working-class literature as a tradition specifically dialoguing with political and social conflicts.

All of the articles presented in this volume clearly argue, or illustrate, the above points. However, this collection also - together with discussions at the many conferences and workshops about working-class literatures in recent years - offers new perspectives, 
accents and insights we believe continue to push our field in new directions.

The starting point for many of this volume's essays is a critique of the use of the concept of working-class literature in a narrow and/or distorting way, or of the fact that literary scholars avoid the concept, denying there is even a national working-class literary tradition. In his essay, Lund argues that in Denmark the concept mainly describes an older literary tradition that is safely in the past-a nostalgia certainly present in many national literatures, including the U.S. where working-class literature is often conceptualized as consisting of only the I930s proletarian movement. By examining Denmark's contemporary literary scene, Lund suggests literary scholars need to continue to resist standardized definitions of working-class literature and expand the way we conceptualize this literature in the present socio-political moment. In South Africa, working-class literature tends to be understood in case studies of certain authors or genres (a limiting move) without dialoguing with larger national trends. As Drwal points out, working-class literature is often subsumed within other conceptual paradigms - such as urban literature-which minimizes discussions of class. In other national literatures, the concept of class is almost completely elided. Zhang in her article on workingclass literature in Singapore points to a "lack of discourse" on the subject of working-class literature as primarily issues of conceptualization and framing.

The reason for the narrowing or distorting conceptualizations of working-class literature varies among nations. Einarsdóttir explains how the right-wing terror plaguing Argentina and destroying many of the Left's cultural institutions have made possible the framing of working-class literature in naturalistic and grotesque ways. Political violence has had a lasting effect on the working class's conceptualization, and she argues the need to reexamine the literary tradition that expands this conceptualization. In Japan, Karlsson points to Japanese government authorities' destruction of the infrastructure of a vibrant working-class literary movement within the interwar period. A similar fate awaited the proletarian-revolutionary literature movement analyzed by Bivens, as well as many other working-class literary movements 
in other countries (the U.S. being one with the rise of Red Scare and McCarthyism). As Lund shows, in Denmark it was not state intervention against the labor movement, but discursive struggles within literary criticism that resulted in working-class literature's disappearance from literary history. In Ireland, on the other hand, nationalism remains an important rival to class-based understandings of both society and literature. The struggles for independence from colonial rule directly affected how the working class has been conceptualized; Pierce argues that to analyze Irish working-class literature means to consider the effect of British rule on the Irish diaspora and its conception of "Irish" identity. In a similar fashion, Drwal explains in her essay that in South Africa, racism was a prime factor in limiting the concept of what constitutes working-class literature.

Regardless of these varying reasons, many of the essays in this volume aim at (re-) introducing the concept of working-class literature and/or changing its meaning. Drwal, for example, argues for imagining the concept of working-class literature not as a fixed category, but as various manifestations of thought being constructed and evolving in space and time, which invites examining circumstances that facilitate or hinder certain cultural exchanges. Zhang's analysis of Singaporean literary history leads to a shift away from categorization of what working-class literature in Singapore is now toward speculation regarding what working-class literature could be. She argues the role of contests promoting working-class literature undercuts the potentiality of the literature as collective ideal. Above all, she argues the poetry competitions for migrant workers organized in Singapore and other Asian countries produce "commodified working-class writings" that should be understood in terms of neoliberal experiments that "potentially hurts the working-class writing community." By reconceptualizing the concept of working-class literature, these articles make these literatures visible in new ways.

By reconceptualizing theories of literature, together these articles also suggest we need to reconceptualize class itself-an idea Lund argues clearly in his essay (although importantly, he believes a traditional concept of working-class literature is relevant today). Karlsson reasons that in Japan, older working-class literature 
can be a resource for understanding class and combatting class injustice in contemporary capitalism. Zhang criticizes alternative framings of literature in Singapore, arguing that the production of literature (and who gets to produce it) is a key to understanding the historical phenomenon of a nation's working class (and, of course, its literature). What Lund, Karlsson, Zhang, and others in this volume show is that research on working-class literature raises questions about what constitutes the working class in these countries, an important question in the second decade of the $2 \mathrm{I}^{\text {st }}$ century. ${ }^{\mathrm{I}}$

Taken together, these articles show that national literatures are not contained within their own borders. National literatures are, at their core, global literatures, not the least because of the constant settling of migrants within new national boundaries while native born citizens leave for distant shores. Pierse shows in his article on the Irish diaspora that to understand "Irish" literature one must understand the literature by Irish immigrants who fled both the famine and, later, the Troubles, and settled in countries like the United States. In Singapore, migrant workers fit uncomfortably within a national literature that often refuses to recognize them. In other words, literature does not fit neatly within a nation's borders but map on the global diasporic routes. While this was an undercurrent in our first volume, this phenomenon is made much more explicit in this volume.

Both this volume and its predecessor argue that working-class literature(s) is a global phenomenon consisting of local literatures. We are confident this constitutes a good starting point for further research, and that it resonates well with key trends in contemporary scholarship about this literature. There are, however, things that are not done in this collection, or in the previous volume. For example, most essays focus almost exclusively on traditional literary forms, such as novels, poems, and plays, whereas phenomena such as comics, "amateur" writing or literature published in labor-movement periodicals or in digital media are largely ignored. We think it would valuable if future research on workingclass literature could adopt a more generous attitude toward the latter part of the concept and pay more attention to other media and public spheres than has hitherto been the case. 
Another important movement in the field could be to theoretically develop a more robust definition of working-class literature(s). In a forthcoming article, Nilsson has taken an initial step in this direction by suggesting that the concept of working-class literature(s) could base itself on a dialectic between historically specific working-class literatures and the theoretical concept of working-class literature. This would mean empirical accounts of different working-class literatures contribute to the concept of working-class literature(s) by making visible phenomena that this concept must be able to accommodate. However, if the concept of working-class literature depends on analyses of many (actually existing) working-class literatures, then this will, in turn, affect these analyses. (It is this analysis that constitutes the dialectical aspect of the conceptual framework of working-class literature(s).) For example, the fact that the general concept of working-class literature is explicitly based on many such literatures makes it less likely that one example of working-class literature is solely declared genuine, and exceptionalities will instead be conceptualized as aspects of the universal. We think this heterogeneity is necessary for a variety of reasons including that a generic definition would prioritize established recognized working-class literature over the literatures of smaller, less recognized literatures, many of whom we have highlighted in our volumes. Our goal has always been dialogue, not definitions, or, perhaps, definitions though dialogue.

We look forward to the continued expansion of the field of working-class literature past its national boundaries, and we are encouraged by scholars gathering and learning at various conferences. It is our hope that scholars will continue to dialogue and build resource platforms focused not only on their research but also on their working-class literature pedagogy. The Center for Working-Class Studies at Youngstown University in the U.S. is a great example of compiling teaching resources together and building scholarly communities of like-minded scholars. Our vision, though, is for more integrated global pedagogical practices. Many of us teach graduate and undergraduate courses that work on dialoguing working-class literatures from a global and historical perspective-Lennon, for example, has introduced two new working-class literature courses with global perspectives at the 
University of South Florida and is currently supervising graduate students on theses and dissertations on this subject. But while these courses are outward looking, they exist only in the space of the classroom and in one-on-one mentorships.

Nilsson has developed an online English-language undergraduate course which has been given for the first time in the Fall of 2020 , open to students from all over the world (for EU citizens, it will even be - like all university courses in Sweden are tuition-free). The course also involves participation from university professors from several continents. This is an improvement of student reach and an initial step toward international professorial collaboration. In the future, we hope to be able to develop this initiative further. Our goal is to have faculty from across the globe teaching together working-class literature(s) both synchronously and asynchronously. These online spaces can compile and encourage dialogue between national experts, organize large national histories, and pool in-depth analysis of particular books. Students from around the globe could collaborate on projects collaboratively, building a platform of ideas together that expand and inspire debate long after the student's graduation. Linking scholarly and pedagogical practices with a consciously built ethos of collaboration can continue to build strong foundations for our shared interests in working-class literature(s) as a continued viable subject of study. An international center of working-class literature - focusing on both research and teaching - could be formed through these collaborations as networks become solidified and projects get published.

These are, of course, future plans that we hope to be a part of as our field continues to expand in new directions. While the future looks bright, there is one thing that has not changed since the publication of the previous volume: class is still an underresearched phenomenon and an under-theorized concept. Workingclass literature is, to be sure, a complex phenomenon. At the same time as it refers to literature, it also brings to the fore questions about class and class injustice in other parts of society. We stated in the previous volume that a more diverse and dynamic understanding of working-class literature could contribute to making visible many aspects of the phenomenon of class. We see presently how 
literature is a powerful force when it comes to discussing class, including in the large number of recently published, internationally acclaimed memoirs and autobiographical novels. For example, Édouard Louis's novels (Who Killed My Father?, The End of Eddy) and Didier Eribon's (Returning to Reims) memoir intellectually explore the intersection of class and sexuality in France. Lyndsey Hanley (Respectable: The Meaning of Class) and Cash Carraway (Skint Estate) explore the way class is reinforced generationally for British working-class women. In the U.S., J.D. Vance's (Hillbilly Elegy) examines working-class generational poverty in Appalachia (and argues for individual escape) while Sarah Smarsh's memoir (Heartland) examines generational poverty of the working-class in Kansas (and argues for collective responses to improve the social and economic conditions of the working-class). In the Macron/ Trump/Johnson era, all of these works are important documents that report on local conditions in an age where class meanings and representations are consistently under tension.

Richard Hoggart (1989, p. vii) stated in his introduction to George Orwell's The Road to Wigan Pier, that, "Each decade we shiftily declare that we have buried class, yet each decade the coffin stays empty." Class is still certainly not dead, but, in a neo-liberal age, there are new tensions, historical phenomena, and aesthetic representations of class that merit careful examination. We hope our volume serves in a small way to keep discussions of class alive and politically relevant.

\section{Acknowledgements}

The authors would like to thank Elizabeth Ricketts and Daniel Mercier, PhD Students at the University of South Florida, for their professionalism and wonderful help in copyediting this book. We are also grateful to our respective universities, The University of South Florida and Malmö University, who were helpful in facilitating us in meeting and working on this endeavor. The making of the book was made possible by generous grants from Stiftelsen Konung Gustaf VI Adolfs fond för svensk kultur [The Foundation King Gustaf VI Adolf's Fund for Swedish Culture], Åke Wibergs stiftelse [Åke Wiberg's Foundation] and Malmö University. 


\section{Endnotes}

I. There is currently some excellent work on national examinations of working-class literature as it relates to the new 2ist economy including Sherry L. Lincoln's The Half-Life of Deindustrialization: Working-Class Writing about Economic Restructuring (Ann Arbor: University of Michigan Press, 2018).

\section{References}

Coles, N. \& Lauter, P. eds. (2017). A History of American WorkingClass Literature. Cambridge, Cambridge University Press.

Goodridge, J. \& Keegan, B. eds. (20I7). A History of British WorkingClass Literature. Cambridge, Cambridge University Press.

Hoggart, R. (1989). “Introduction.” In G. Orwell, The Road to Wigan Pier. Harmondsworth, Penguin, pp. v-xii.

Nilsson, M. (2014). Literature and Class. Aesthetical-Political Strategies in Modern Swedish Working-Class Literature. Berlin, Humboldt-Universität.

Nilsson, M. (forthcoming). "Swedish Exceptionalism and WorkingClass Literature.” In J. Bjerring-Hansen, T. Jelsbak \& A Estera Mrozewicz, eds. Scandinavian Exceptionalisms. Culture, Society, Discourse. Berlin, Humboldt University.

Pierse, M. ed. (2018). A History of Irish Working-Class Writing. Cambridge, Cambridge University Press. 